\title{
Habitat associations of epigeal spiders in upland calcareous grassland landscapes: the importance for conservation
}

\author{
Ashley Lyons $^{1}$ (D) Paul A. Ashton ${ }^{1}$ (D) Ian Powell $^{1} \cdot$ Anne Oxbrough $^{1}$ (D)
}

Received: 24 July 2017 / Revised: 27 November 2017 / Accepted: 11 December 2017 /

Published online: 16 December 2017

(C) The Author(s) 2017. This article is an open access publication

\begin{abstract}
Upland calcareous grassland landscapes are typically comprised of a matrix of calcareous grassland, acid grassland and limestone heath plant communities. This matrix of habitats is produced by a combination of underlying geology, climate and management. These landscapes are typically managed through grazing, with management targeted to maintain particular plant communities in the calcareous grassland habitat, whilst patches of acid grassland and limestone heath are not targeted by conservation management. The biodiversity value of acid grassland and limestone heath patches within the calcareous grassland matrix are unknown. This study provides the first assessment of their biodiversity value by examining aspects of epigeal spider diversity supported by these non-target habitat patches in comparison to calcareous grassland. Spiders were sampled in each habitat from April to August 2014 using pitfall traps across three upland regions in Great Britain. Spider species assemblages were distinct between limestone heath and both grassland types. Distinction in species assemblages are likely due to differences in vegetation structure and microclimate, e.g., humidity, degree of shade. Each habitat type supported several rare species (e.g., Jacksonella falconeri, Agyneta subtilis) revealing the contribution
\end{abstract}

Communicated by David Hawksworth.

Electronic supplementary material The online version of this article (https://doi.org/10.1007/ s10531-017-1488-4) contains supplementary material, which is available to authorized users.

Ashley Lyons

lyonsa@edgehill.ac.uk

Paul A. Ashton

ashtonp@edgehill.ac.uk

Ian Powell

powelli@edgehill.ac.uk

Anne Oxbrough

oxbrouga@edgehill.ac.uk

1 Department of Biology, Edge Hill University, Biosciences Building, St Helens Road, Ormskirk, Lancashire L39 4QP, UK 
to spider fauna. The distinct spider species assemblage and presence of rare species in limestone heath patches demonstrate their importance in the upland calcareous grassland matrix. This study highlights the value of monitoring biodiversity in non-target habitats within a habitat matrix alongside those that are actively targeted by management.

Keywords Heath · Acid grassland - Limestone - Calcareous grassland matrix · Grazing · Grassland management $\cdot$ Conservation

\section{Introduction}

Calcareous grassland, considered among the most species rich and diverse habitats for many species groups in Europe, underwent wide scale loss and degradation following post 1950s agricultural intensification and as such has become the focus of conservation efforts (Willems 2001; Fischer and Stocklin 1997; Poschlod et al. 2005; Poschlod and Wallis de Vries 2002; Roesch et al. 2013; Wallis De Vries et al. 2002). Afforded protection under Annex I of the EU habitats directive, an estimated 595, 973 ha is protected in the Natura 2000 network across EU member states (Calaciura and Spinelli 2008). Their management typically aims to maintain particular plant communities through prevention of succession and domination by one or few species (Willems 2001; Wallis de Vries et al. 2002).

In upland regions of the UK, high stocking densities of sheep were implicated as a major cause of habitat deterioration and the decline of associated plants, invertebrates and birds (Dennis et al. 2008; Fuller and Gough 1999). In an attempt to conserve the characteristic vegetation of rare upland calcareous grassland, which covers just $0.1 \%(22,000-25,000$ ha) of total UK land cover (calculated from Maddock 2008; DEFRA 2013), there has been a reduction in stocking levels within the last decade.

Upland calcareous grassland landscapes are typically comprised of a matrix of calcareous grassland, acid grassland and limestone heath plant communities. This matrix of habitats is produced by a combination of underlying geology, climate and grazing management (Rodwell 1992; Rodwell et al. 2007). Thin, well drained, lime rich soils found on limestone bedrock provide suitable conditions for calcareous grassland (Rodwell et al. 2007; Joint Nature Conservation Committee 2007). Superficial deposits of glacial till or loess among the thin soil overlying the limestone bedrock produce patches of plant communities within the calcareous grassland which are dominated by calcifuge species (Rodwell 1992; Dixon 1982). Under reduced intensity sheep grazing, these patches are either maintained as acid grassland (dominated by Nardus stricta) or develop into the climax community of limestone heath [EC Habitats Directive Annex 1 (Joint Nature Conservation Committee 2013)]. The selective grazing behaviour of sheep results in particular vegetation patches experiencing different effective stocking densities (Dennis et al. 2015; Grant et al. 1985). At low stocking densities sheep restrict grazing to vegetation patches containing preferred plant species resulting in effectively ungrazed patches of less preferred vegetation (Hester and Baillie 1998).

Little is known about the biodiversity value of these habitat patches in the calcareous grassland matrix. While the calcareous grassland itself is recognised as a priority habitat for conservation and targeted by conservation management, the value of patches of limestone heath and acid grassland in the grassland matrix is often overlooked, and not targeted by management, despite the former being included under Annex 1 of the EC Habitats Directive (Joint Nature Conservation Community 2013). Such habitats outside of the 
calcareous grassland matrix are known to support distinct plant and animal assemblages (Dennis et al. 2001; Littlewood et al. 2006).

Spiders play an important role in the functioning of all ecosystems, occupying an important role in terrestrial food webs as both predators and prey (Turnbull 1973; Uetz 1991). They encompass a wide range of foraging strategies and as such are differentially sensitive to variations in vegetation architecture and disturbance (Barriga et al. 2010; Dielh et al. 2013; Gibson et al. 1992). Differences in foraging strategies are linked to vegetation structure and disturbance (Alderweireldt 1994; Bell et al. 2001; Uetz 1991). Ground hunting species require a heterogeneous sward of open patches to search for prey and taller vegetation for refuge (Maelfait and De Keer 1990), whereas orb web weaving spiders select structurally complex vegetation that provides increased web anchorage points (Dielh et al. 2013; Langellotto and Denno 2004; McNett and Rypstra 2000). The differences in foraging strategy, activity and substrate utilisation amongst species make grouping spiders into guilds a useful tool for examining functional differences among habitats (Corcuera et al. 2015; Schweiger et al. 2005). It would be expected that the contrasting structure and differences in relative stocking densities of the non-target habitats in the calcareous grassland matrix will impact both potential niche availability and microclimate, e.g., humidity and temperature stability, thus providing conditions suited to different species or hunting guilds.

Furthermore, spider diversity correlates with total arthropod diversity over a wide range of cultivated habitats in Central Europe (Duelli and Obrist 2003). Thus, their ecological requirements and relationship with other taxa make them a useful group for studying differences in diversity among contrasting habitat types.

This study is the first to investigate the biodiversity value of non-target habitats within the upland calcareous grassland matrix, using spiders as a model group. Specifically, it will ask:

1. How do spider assemblages differ among habitats in the upland calcareous grassland matrix?

2. How does the proportion of functional guilds, measured by hunting strategy, differ among habitat types in the matrix?

3. Do non-target habitats support species of conservation interest?

\section{Methods}

\section{Study sites}

Three sites of extensive areas of calcareous grassland (size 35-525 ha, median 76 ha) were selected for study across geographically distinct regions separated by 14-48 km in Northern England $\left(54^{\circ} 29^{\prime} 44.41^{\prime \prime} \mathrm{N}, 002^{\circ} 33^{\prime} 20.03^{\prime \prime} \mathrm{W}\right)\left(54^{\circ} 09^{\prime} 03.76^{\prime \prime} \mathrm{N}, 002^{\circ} 06^{\prime} 00.29^{\prime \prime} \mathrm{W}\right)$ $\left(54^{\circ} 08^{\prime} 44.37^{\prime \prime} \mathrm{N}, 002^{\circ} 19^{\prime} 17.54^{\prime \prime} \mathrm{W}\right)$. Each study site was under the same management of sheep grazing with a stocking intensity of $<0.24 \mathrm{LU} \mathrm{ha}^{-1}$ year $^{-1}$ that had been in place for a minimum of 10 years prior to study. Elevation ranged from 213 to $383 \mathrm{~m}$, median $355 \mathrm{~m}$. Soil across the sites was generally base rich with some deposits of glacial till and peat resulting in each site containing three habitat types: a matrix of calcareous grassland, targeted by conservation management, along with scattered patches of Nardus stricta grassland and limestone heath, both non-target habitats. The habitats were defined as: calcareous grassland which had a species rich sward with a mean sward height of $8.09 \mathrm{~cm}$ over 
the sampling period, limestone heath which occurred in patches exceeding $20 \mathrm{~m}^{2}$ and was dominated by mature stage Calluna vulgaris, and acid grassland which was dominated by $N$. stricta, and again occurred in patches exceeding $20 \mathrm{~m}^{2}$. In addition, though vegetation height in acid grassland and heath was not measured there was an observable distinction, the latter was taller with the canopy always exceeding $30 \mathrm{~cm}$. Further, the ground layer of heath largely lacked vegetation, instead having a covering of heather litter. In contrast, both the calcareous grassland and acid grassland had a well-developed ground layer, with the acid grassland having dense tufts of $N$. stricta.

Three representative samples of each habitat type were selected as replicates at each study site. Each habitat replicate was spaced a minimum of $51 \mathrm{~m}$ (median $226 \mathrm{~m}$ ) from other replicates to ensure statistical independence of samples (Digweed et al. 1995), and a minimum of $50 \mathrm{~m}$ away from disturbance, e.g. footpaths, water troughs, etc. Spatial independence of samples was confirmed with Moran's I based on nearest neighbour distances for all 27 locations for spider abundance (Moran's I \pm SD: $-0.06 \pm 1.14, p=0.87$ ) (Bivand et al. 2014). Within each site, collections of epigeic spiders were conducted between May and August 2014.

\section{Epigeal spider sampling}

Within each habitat replicate, six pitfall traps, spaced $2 \mathrm{~m}$ apart, were established to capture epigeal spiders. Traps consisted of a plastic cup approximately $7 \mathrm{~cm}$ in diameter and $9 \mathrm{~cm}$ deep and covered with a square plastic lid suspended $1 \mathrm{~cm}$ from the ground by pegs to prevent rain water and debris from entering. These were filled to $1 \mathrm{~cm}$ depth with propylene glycol to act as a killing and preserving agent. To prevent traps being trampled or interfered with by livestock each trap was protected by a secured cage made from $2.5 \mathrm{~cm} \times 2.5 \mathrm{~cm}$ gauge mesh. These cages do not affect the trapping rates of ground-dwelling invertebrates (Oxbrough et al. 2012). Where traps were set in patches of acid grassland or limestone heath they were placed in the centre of the patch, where they were set in calcareous grassland they were placed a minimum of $50 \mathrm{~m}$ from other habitat types. Traps were set between 05/05/2014 and 21/08/2014 and were changed every 21 days, giving a total of 105 trap days. Samples from five of the traps within each location were pooled for analysis, with the sixth kept as a spare in case of trap loss.

Pitfall traps are a widely used sampling method to catch active ground dwelling invertebrates in grasslands and heathlands (Gardner et al. 1997; Haysom et al. 2004; Lyons et al. 2017). This method estimates relative invertebrate activity rather than an absolute measure of density, reflecting species abundance and movement rates (Greenslade 1964; Mazia et al. 2006). Consequently, they are less likely to capture sedentary species or those occupying higher levels of vegetation. Nevertheless, their high catch rate, ease of setting up and objectivity render their use appropriate in large scale studies with multiple sites (e.g., Oxbrough et al. 2012; Taboada et al. 2010; Niemela et al. 1993).

All adult spiders were identified to species level using Roberts (1993) and nomenclature follows World Spider Catalogue (2017). Since it was not possible to reliably identify most juvenile species these were excluded from the study. Information on conservation status was gathered from Dawson et al. (2008). Spider reference specimens are housed at the Edge Hill University Department of Biology arthropod collection. 


\section{Spider hunting guilds}

Following identification to species, spiders were separated into five guilds based on hunting strategies suggested by Cardoso et al. (2011): sheet web weavers, ground hunters, space web weavers, ambush hunters and other hunters. However, whilst Cardoso et al.'s (2011) classification includes Pachygnatha degeeri as an orb web spinner, in this study since only adult specimens were identified, it is placed in the ground hunter guild in recognition of its active hunting strategy as an adult. The list of spider species and associated guilds is included in Online Resource 1.

\section{Data analysis}

Five of the pitfall traps in each habitat replicate were pooled across the full sampling period. To account for differences in trapping effort all samples were standardised to trap day by calculating the abundance of each species at each location and dividing it by the number of actual trap days at that location and then multiplying it by the maximum number of trap days across all locations (105), a standard method used in studies using pitfall trapping (Bergeron et al. 2013; Blanchet et al. 2013: Pinzon et al. 2013).

Statistical analyses were carried out with $\mathrm{R}$ statistical software (version 3.2.0.) ( $\mathrm{R}$ Development Core Team 2016) and EstimateS (version 9.1.0) (Colwel 2013).

Raw spider species data (not standardised by trap day) was used to examine differences in species richness among habitats using sample based rarefaction calculated using EstimateS, version 9.1.0 (Colwel 2013) with rarefaction curves produced in $\mathrm{R}$ and scaled by the number of individuals. This technique accounts for differences in sampling effort by standardising species richness for the number of individuals within a sample. Rarefaction estimates the number of species expected in a random sub-sample extracted from a larger sample (Chao 2005; Magurran 1988, 2004).

Differences in spider abundance among habitat types were examined with generalised linear mixed models (GLMMs) performed with negative binomial errors using the glmer function of the lme4 package (Bates et al. 2015). Habitat was modelled as a fixed factor with region modelled as a random factor. Negative Binomial errors were used to combat overdispersion of Poisson errors (dispersion = 43.82) (Thomas 2017). The model was tested for significance using the Anova function of the Car package (Fox and Weisberg 2011) and post hoc Tukey pairwise comparisons were used to test for differences among habitat types, correcting $\mathrm{p}$ values for multiple comparisons with the Holm method using the glht function of the multcomp package (Hothorn et al. 2008).

The proportion of each hunting guild among habitats was compared using GLMMs computed with Binomial errors. Habitat was modelled as a fixed factor and region modelled as a random factor. GLMMs were computed for ground hunters and sheet web weavers. Space web weavers, ambush hunters and other hunters were not examined in this way as the abundance of each group was too small and contained too many zero observations. Each model was tested for overdispersion of Binomial errors (dispersion: ground hunters $=14.69$; sheet web weavers $=9.77$ ). To correct for overdispersion, observation level random effects were included in the overall model (Harrison 2014). Bonferonni correction was applied to the confidence intervals to account for the multiple testing of the abundance data (e.g., split into five guilds). However, as the number of individuals was not divided equally among the five guilds the confidence intervals at which statistical significance was determined using the Bonferonni correction were not set at equal (e.g., 0.05/5) but rather 
as the proportion that each guild comprised of the data set (required confidence intervals to infer significance: ground hunters $<0.02$; sheet web weavers $<0.028$ ) following Neuwald and Green (1994). GLMM model outputs are included in Online Resource 2.

Spider species composition was examined through Redundancy Analysis (RDA) computed on Hellinger transformed spider species data using the RDA function in the vegan package in R (Oksanen et al. 2016). Habitat was included as the main term in the model with region included as a random factor. Permutation test, with 9999 permutations, was used to test final significance of the model.

Beta diversity $(\beta)$, defined as variability in spider species composition (Anderson et al. 2006), among habitats was quantified using the betadisper function in the vegan package in $\mathrm{R}$ (Oksanen et al. 2016), followed by permutation test (999 permutations) to test for significance. Betadisper measures $\beta$ diversity by assessing the variability in average distances from the group centroid among individual sampling units (Anderson et al. 2006). The analysis was conducted on spider species data transformed into a dissimilarity matrix calculated with the Simpson dissimilarity index (bsim) (Koleff et al. 2003). Simpson dissimilarity index is appropriate for use in this instance as it measures differences in species composition independent of richness gradients (Baselga 2007; Koleff et al. 2003). The dissimilarity matrix is presented graphically in a principal coordinate analysis (PCoA) plot based on group centroids.

Significant associations of spider species with each habitat type were determined using indicator species analysis (Dufrene and Legendre 1997) using the indval function of the labdsv package (Roberts 2015). Indicator Species Analysis produces indicator values between 0 and 1 , a value of 1 represents a perfect indicator that is always present in a particular treatment and is exclusive to that treatment (McCune et al. 2002). Significance of indicator values was assessed using a Monte Carlo randomisation procedure with 4999 iterations. Significant indicator values infer species associations with each habitat type as a mechanism to characterise habitat use by spiders.

\section{Results}

A total of 12,878 individual spiders from 89 species were collected. 4066 (31.57\% of overall abundance) of these were juveniles and $103(0.80 \%)$ were damaged specimens. Neither of these groups could be identified and were therefore omitted from the data set. A total of 8709 individuals from 89 species of nine families representing five hunting guilds were included in the following analyses. A full list of species is given in Online Resource 1. Overall, only three species individually made up more than $5 \%$ of the total spider abundance, together totalling 29\% of the overall catch: Pardosa pullata (14.13\%), Pachygnatha degeeri $(8.24 \%)$ and Silometopus elegans $(6.88 \%)$.

\section{Spider diversity}

Rarefaction curves showed that spider species richness did not differ among habitats (Fig. 1), as indicated by the overlap in confidence intervals. Spider abundance was different among habitats $\left(\chi_{2, N=27}^{2}=9.69, \mathrm{p}<0.01\right)$, with greater abundance in acid grassland and calcareous grassland compared with heath $(\mathrm{z}=2.65, \mathrm{p}<0.05 ; \mathrm{z}=2.71, \mathrm{p}<0.05$ respectively) (Fig. 2). 
Fig. 1 Sample based rarefaction curves scaled by the number of individuals, indicating spider species richness. $A$ acid grassland, $C$ calcareous grassland, $H$ heath. Grey bars indicate $95 \%$ confidence intervals

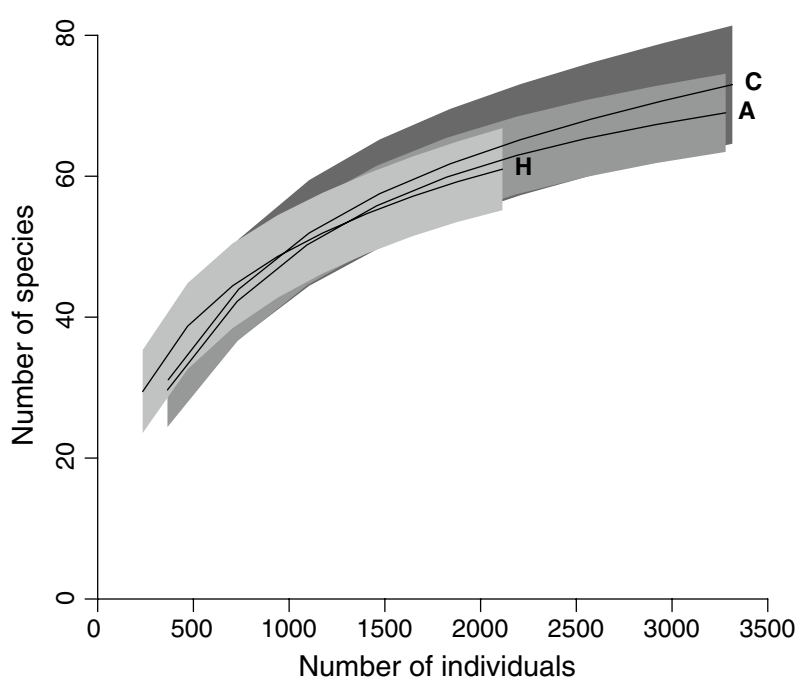

Fig. 2 Spider abundance among habitat types. The letters indicate significance of post hoc Tukey test, where letters are different this indicates a significant difference $(\mathrm{p}<0.05)$

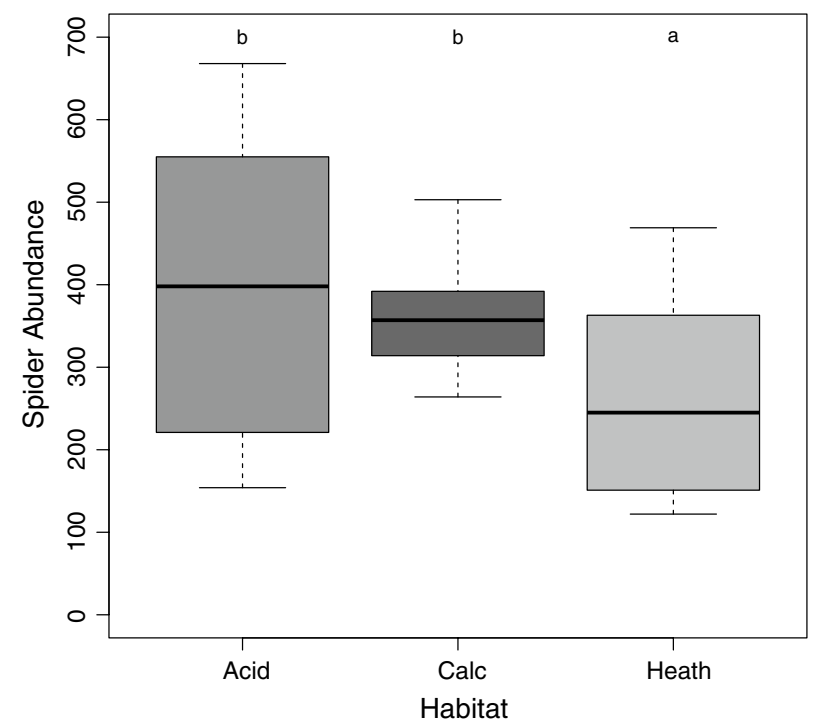

\section{How do spider assemblages differ among habitats in the calcareous grassland matrix?}

Spider species assemblage differed significantly among habitats $\left(\mathrm{F}_{2,22}=5.40, \mathrm{p}=0.001\right)$ which accounted for $26.32 \%$ of the variability in the overall model. The conditional variable of region accounted for $20.08 \%$ of the variability in the overall model. The first two RDA axes accounted for $32.92 \%$ of the variation in the model after the contribution of region was removed (Fig. 3). The removal of region enables the comparison of habitat types without the effects of unmeasurable variables which are a product of regional 
Fig. 3 RDA of spider assemblage by habitat type. Region partialled out. Variation in the model represented by RDA1 was significant $\left(\mathrm{F}_{1,22}=8.77\right.$, $\mathrm{p}=0.001)$ whilst RDA2 was not significant $\left(\mathrm{F}_{1,22}=2.03\right.$, $\mathrm{p}=0.081)$. Circles $=$ calcareous grassland, triangles $=$ acid grassland, squares = heath

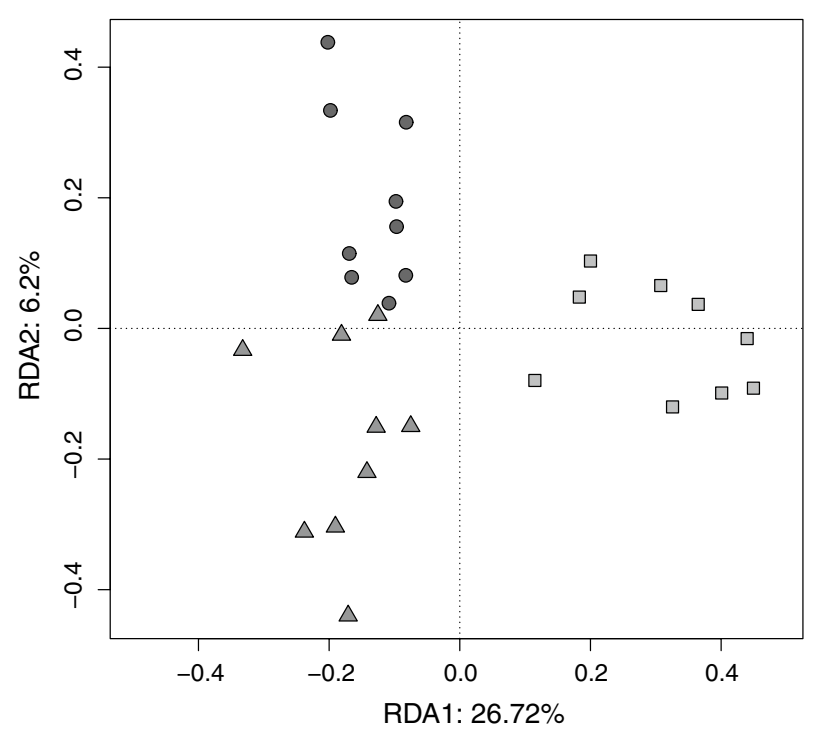

variation. The contribution of RDA axis one to the variation in the model was significant $\left(\mathrm{F}_{1,22}=8.77, \mathrm{p}=0.001\right)$ and represents a separation of heath from both acid grassland and calcareous grassland (Fig. 3). RDA2 distinguishes acid grassland from calcareous grassland, however, this axis was not significant $\left(\mathrm{F}_{1,22}=2.03, \mathrm{p}=0.081\right)$.

$\beta$ diversity was significantly different among habitat types $\left(\mathrm{F}_{2,24}=4.95, \mathrm{p}=0.02\right)$. Significant differences were found in the pair wise comparisons of the habitats acid grassland and heath $(\mathrm{p}=0.043)$, and calcareous grassland and heath $(\mathrm{p}=0.008)$, but not calcareous grassland and acid grassland ( $\mathrm{p}>0.05$ ). The PCoA plot (Fig. 4) shows greater spread of

Fig. 4 Principal coordinate analysis plot showing average dissimilarity from individual observations to their group centroids. $H$ heath, $A$ acid grassland, $C$ calcareous grassland. Permutation test: Heath-acid grassland $\mathrm{p}=0.04$, heath-calcareous grassland $\mathrm{p}=0.004$, acid grassland-calcareous grassland $\mathrm{p}=0.54$

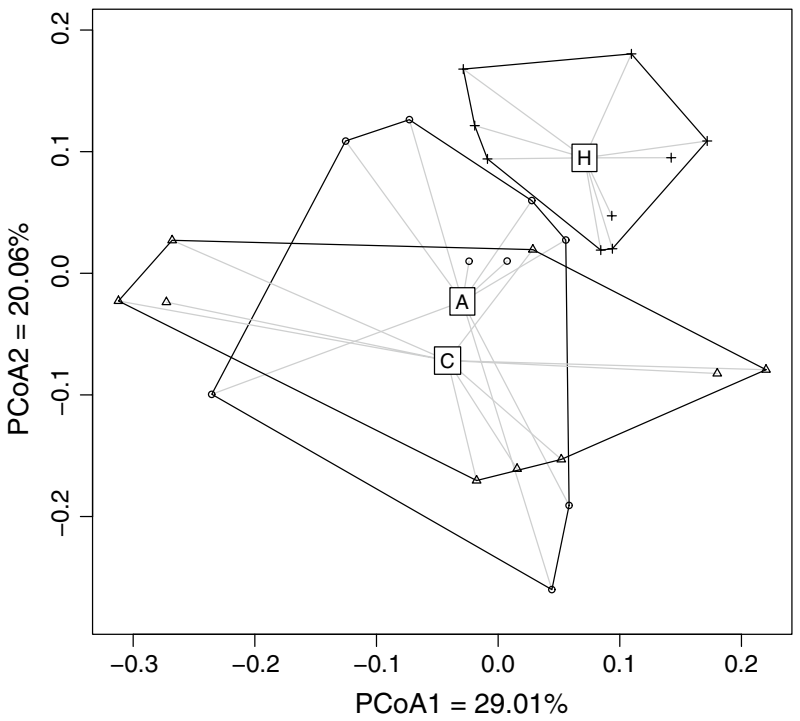


points around the centroid in both acid grassland and calcareous grassland along both axes compared to heath, indicating they have greater $\beta$ diversity.

\section{How does functional diversity, measured by hunting strategy, differ among habitat types in the matrix?}

The most abundant guild was sheet web weavers (5233 individuals, 56.03\%), then ground hunters (3783 individuals, 40.51\%), other hunters (166 individuals, 1.78\%), space web weavers (100 individuals, 1.07\%) and ambush hunters (58 individuals, $0.62 \%$ ).

The proportion of sheet web weavers was significantly different among habitats $\left(\chi_{2, N=27}^{2}=77.44, \mathrm{p}<0.028\right)$ (based on Bonferroni corrected $\mathrm{p}$ values) and was driven by a greater proportion in calcareous grassland compared to acid grassland $(z=3.46$, $\mathrm{p}<0.001)$ and a greater proportion in heath compared to acid grassland and calcareous grassland $(\mathrm{z}=8.75, \mathrm{p}<0.001 ; \mathrm{z}=5.40, \mathrm{p}<0.001$ respectively) (Fig. 5). The proportion of ground hunters was also significantly different among habitats $\left(\chi_{2, N=27}^{2}=52.84\right.$, $\mathrm{p}<0.001)$ with a greater proportion in acid grassland compared to calcareous grassland and heath $(\mathrm{z}=0.57, \mathrm{p}<0.01 ; \mathrm{z}=1.57, \mathrm{p}<0.001$ respectively) and a greater proportion in calcareous grassland compared to heath $(\mathrm{z}=1.01, \mathrm{p}<0.001)$ (Fig. 5).

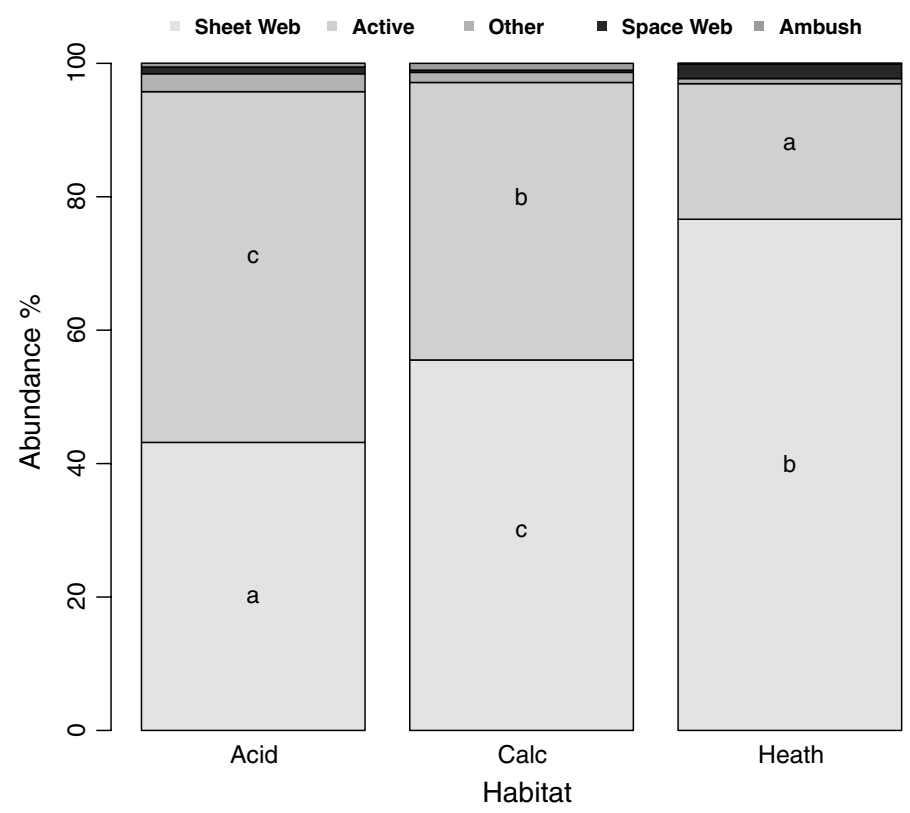

Fig. 5 The proportion that each spider hunting guild makes up in each habitat type. The letters indicate significance of post hoc Tukey test within each guild; where letters are different this indicates a significant difference $(\mathrm{p}<0.05)$ in a guild's proportional abundance among the habitat types. Sheet Web sheet web weavers, Active ground hunters, Other Hunter 'other' hunter, Space Web space web weavers, Ambush ambush hunters 


\section{Do non-target habitats support species of conservation interest?}

Indicator species analysis revealed a total of three species associated with acid grassland, four with calcareous grassland and eight associated with heath (Table 1). All three species associated with acid grassland were from the sheet web weaver guild, two of which have a preference for damp habitat conditions. Three of the four species associated with calcareous grassland were from the sheet web guild, including Jacksonella falconeri which is classified as endangered by Dawson et al. (2008). All three species have preferences for grassland habitats. The fourth species associated with calcareous grassland belongs to the ground hunter guild and is a generalist species. Of the eight species associated with heath, six were from the sheet web guild, including Agyneta subtilis which is classified as vulnerable by Dawson et al. (2008). The further two associated species were from the ground hunter and space web weaver guilds. With the exception of Walckenaeria acuminata, all species associated with heath have a known preference for woodland or heathland (Table 1).

Assessment of conservation status according to Dawson et al. (2008) revealed two endangered species: J. falconeri (17 individuals) and Porrhomma egeria (2 individuals), and six vulnerable species; A. subtilis (274 individuals); Walckenaeria dysderoides (4 individuals); Allomengea scopigera (3 individuals); Trichopternoides thorelli (2 individuals); Walckenaeria inscisa (1 individual) and Walckenaeria monoceros (1 individual) (Table 2).

\section{Discussion}

\section{How do spider assemblages differ among habitats in the calcareous grassland matrix?}

This study found distinct spider species assemblages between heath and both grassland habitat types, the latter not differing from each other. Additionally, despite there being no difference in species richness, $\beta$ diversity was greater in both grassland habitat types compared to heath, though again the former did not differ from each other. This indicates that spider species assemblage is driven by turnover of species (both losses and gains) and is not simply a product of recruitment of species, as was also recognised by Dennis et al. (2015) and van Klink et al. (2013) in grasslands under varying management intensities.

Indeed, the differences in species assemblage are likely a result of contrasting habitat structure, which is known to impact spiders (Bell et al. 2001; Morris 2000; Uetz 1991). There is considerable variation in the structure of grasslands and heathlands (García et al. 2010). In the present study, though heath had greater overall vegetation height than the grassland habitats, the ground layer was denser in the latter resulting in greater structural complexity at the ground level in grasslands (personal observation). Indeed, increased structural complexity provides increased potential for niche differentiation (Woodcock et al. 2009). In structurally complex swards containing a full range of phenological structures there is increased potential for resource utilisation for phytophagous prey taxa (Denno 1980; Woodcock et al. 2009; Morris 2000), and greater abundance than in structurally less complex swards (Dennis et al. 1998, 2008). Further, as structural complexity increases, the availability of niches suitable for the construction of different types of webs also increases (Bell et al. 2001; Robinson 1981; Woodcock et al. 2009). 







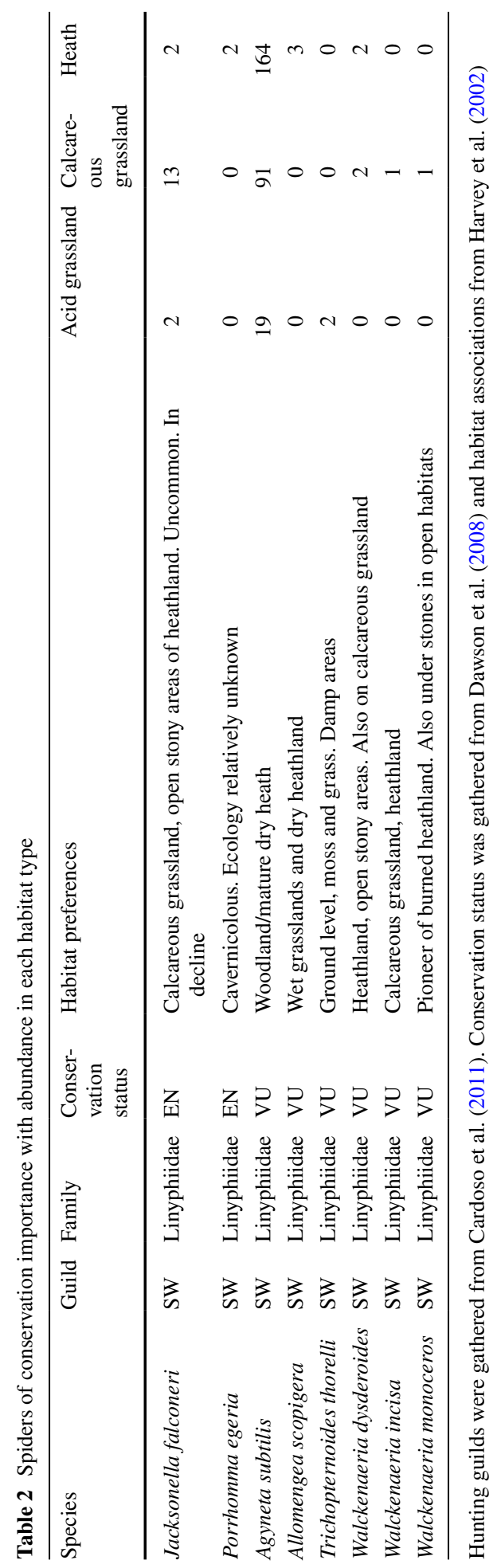




\section{How does the proportion of functional guilds, measured by hunting strategy, differ among habitat types in the matrix?}

Overall, differences of the proportions of hunting guilds among habitat types likely reflect habitat structural differences. The dominance of sheet web weavers in heath and the significantly reduced proportion of ground hunters compared to the grassland habitats reflects differences in ground level vegetation structure, differences in microclimate and shade. Differences of shade among heath and grasslands habitats is highlighted by the much lower abundance of Xysticus cristatus, a shade intolerant ambush hunter which is rare in woodlands and closed canopy habitats (Spider and Harvestman Recording Scheme 2017). This is further reflected by all but one of the species associated with heath having a habitat preference for woodland or heathland, six of which occupy the ground zone, often casting webs close to the ground, e.g., Peponocranium ludicrum (Harvey et al. 2002). The single heath associated species without a particular preference for woodland or heathland, Walckenareia acuminata is a habitat generalist, but again occupies the ground zone (Harvey et al. 2002).

The greater proportion of ground hunters in grassland habitats reflects the crucial role of refuges within the sward, such as those of tussock forming grasses, in habitat suitability for ground dwelling predators (Woodcock et al. 2009; Maelfait and De Keer 1990). For example, Trochosa terricola, associated with calcareous grassland in the present study, utilises tufts of Festuca ovina, the second most abundant plant species in these upland calcareous grasslands (Lyons et al. 2017). Further, in both grassland habitats the ground hunter guild was dominated by Pardosa species, a genus known to also utilise different components of vegetation structure for prey capture, overwintering and refuge from predators (Bristowe 1958; Maelfait and De Keer 1990). In contrast, the ground layer of the heather lacked the structural heterogeneity of the grassland habitats and is reflected by the lower proportion of ground hunters. Indeed, Pardosa nigriceps, the ground hunter associated in this study with heath, is a semi arboreal species (Vlijm and Kessler-Geschiere 1967) able to utilise the contrasting structural complexity of the mature heather and as such is not as reliant on ground vegetation heterogeneity as other species in the Pardosa genus.

The reduced proportion of sheet web weavers in acid grassland compared to calcareous grassland was seemingly replaced by a greater proportion of active hunters, notably due to the greater abundance of Pachygnatha degeeri. McFerran et al. (1994) and Maelfait and De Keer (1990) found $P$. degeeri was an indicator species of less intensively managed sites. Their greater abundance in acid grassland in the current study may reflect the lower effective stocking density in this habitat type, which is a product of sheep grazing behaviour. Sheep are preferential grazers, able to select preferred plant species within a sward (Grant et al. 1985). Where preferred vegetation is available sheep avoid N. stricta (Grant et al. 1985), the dominant species in the acid grassland habitat. This likely results in a lower effective stocking density in the acid grassland habitat compared to the calcareous grassland, thus providing suitable conditions for $P$. degeeri.

\section{Do non-target habitats support species of conservation interest?}

Both calcareous grassland and the non-target habitats of acid grassland and heath supported several notable species. Though some of these species were rare in the dataset (occurring as doubletons and singletons), making it difficult to make specific habitat determinations, 
this study provides the first evidence of the importance of these landscapes for supporting rare species and highlights the need for further monitoring and research.

Jacksonella falconeri, found in each habitat type (total of 17 individuals) but most abundantly in calcareous grassland (13 individuals), is classed as endangered in Britain (Dawson et al. 2008) (Table 2), and has shown a steep decline over the last 20 years (Spider and Harvestman Recording Scheme 2017). Threats to this species include degradation and loss of calcareous grassland and heathland (Spider and Harvestman Recording Scheme 2017). The close proximity of these two habitat types in the present study may be beneficial for its long-term conservation.

Calcareous grassland also supported four species classed by Dawson et al. (2008) as vulnerable in Britain: A. subtilis, W. dysderoides, W. incisa and W. monoceros, the latter two represented exclusively in this habitat by single individuals (Table 2). W. monoceros, which occurs under stones in open inland habitats (Harvey et al. 2002) and is also identified as a pioneer species of heather (Merrett 1976), has also previously been recorded in calcareous grassland (Spider and Harvestman Recording Scheme 2017). It has experienced steep decline in Britain over the last 20 years, with both the loss of heathland and the lack of management to maintain early successional stages implicated in this decline (Spider and Harvestman Recording Scheme 2017). W. dysderoides, which was found in calcareous grassland and the non-target habitat of heath in the present study, is an uncommon species found in heathland, woodlands and both acid and calcareous grasslands (Harvey et al. 2002). The loss of calcareous grassland and heath have been recognised as potential causes of its long-term decline, though understanding of its ecology remains relatively unknown, rendering it difficult to appreciate the mechanisms of its decline (Spider and Harvestman Recording Scheme 2017).

There were a further two vulnerable species recorded in the non-target habitat of acid grassland (Table 2): A. subtilis and T. thorelli, the latter represented exclusively in this habitat by two individuals.

In heath two individuals of $P$. egeria, classed as endangered in Britain (Dawson et al. 2008), were recorded (Table 2). P. egeria is predominantly a cavernicolous species which usually occurs in low numbers (Harvey et al. 2002) and is noted as having suffered a $70 \%$ decline (Spider and Harvestman Recording Scheme 2017).

In addition to the endangered species mentioned, heath also supported three species classed by Dawson et al. (2008) as vulnerable (Table 2); A. scopigera which was again exclusive to this habitat, W. dysderoides and A. subtilis, the latter of which occurs in greater abundance in this habitat (164 individuals) compared to each of the grassland habitat types (acid grassland $=19$ individuals; calcareous grassland $=91$ individuals). A. subtilis has been noted as maintaining high densities in mature heather of dry heath after burning (Merrett 1990). Its comparatively high abundance in heath in the present study again highlights the importance of this habitat type in the calcareous grassland matrix.

\section{Conservation implications}

The absence of targeted management of heath patches within the upland calcareous grassland matrix, coupled with the low stocking density of sheep, results in them being relatively undisturbed. Consequently, they support a distinct spider assemblage and a number of notable species. It is suggested therefore, that management recommendations consider the full spectrum of the species pool and their ecological requirements. To this effect, 
the current study greatly improves our understanding of rare species and their ecological needs.

Whilst it is acknowledged that due to rarity of some species in this study (doubletons and singletons) specific habitat associations cannot be determined, they do occur in the landscape and as such it is still incumbent to consider their presence in these areas. For example, prior to this study just 85 individual $P$. egeria had been recorded in Great Britain since 1894 (Spider and Harvestman Recording Scheme 2017). Consequently, little is known about its ecological requirements or life history, rendering it difficult to make conservation management recommendations despite their endangered status. It is therefore strongly recommended that rare species such as these are targeted for study in these nontarget microhabitats using a range of sampling techniques to discern if they have established populations and what their ecological requirements are. Developing such an understanding will enable recommendations on management practices to enhance conservation efforts to be made.

Further, though this study targeted active epigeal species it is acknowledged that some species may also be found in the higher vegetation layers or will be sedentary. It is unknown how these respond to different habitat patches, although research has shown high congruence between ground dwelling and higher vegetation living spiders in terms of changes in biodiversity between habitats (Oxbrough et al. 2009). Despite this, pitfall trapping is a well-used and robust method for sampling ground-active spiders, rendering the management recommendations presented here an important first step for the conservation of spiders in this important landscape.

\section{Conclusions}

The importance of the calcareous grassland habitat mosaic has been demonstrated in this study by the distinct species assemblages between heath and the grassland habitats and by the different proportion of guilds in these assemblages.

This study highlights the value of monitoring biodiversity in non-target habitats within a habitat matrix alongside those that are actively targeted by management. Understanding which species occur within these non-target habitats and their ecology is vitally important in making management decisions. Integrating research outputs into conservation management decisions is vital and further research into the overall biodiversity value of these nontarget habitats within the calcareous grassland matrix is urged.

Acknowledgements The authors would like to thank two anonymous reviewers for their constructive comments leading to substantial improvements to the manuscript. The authors would also like to thank Natural England, Yorkshire Dales National Park Authority, Lowther Estates and the National Trust for their assistance in providing permission for sampling sites. Particular thanks to Rob Petley-Jones, Colin Newlands and Peter Welsh for assistance with site information and to colleagues at Edge Hill University (notably Thom Dallimore, Matt Esh and Natalie Merritt) for assistance with fieldwork and sorting invertebrate samples. Special thanks to the Post Office in Orton for keeping us supplied with toffee tiffin for the duration of fieldwork.

Funding This study was funded by Edge Hill University.

Open Access This article is distributed under the terms of the Creative Commons Attribution 4.0 International License (http://creativecommons.org/licenses/by/4.0/), which permits unrestricted use, distribution, and reproduction in any medium, provided you give appropriate credit to the original author(s) and the source, provide a link to the Creative Commons license, and indicate if changes were made. 


\section{References}

Alderweireldt M (1994) Prey selection and prey capture strategies of linyphiid spiders in high-input agricultural fields. Bull Br Arachnol Soc 9:300-308

Anderson MJ, Ellingsen KE, McArdle BH (2006) Multivariate dispersion as a measure of beta diversity. Ecol Lett 9:683-693

Barriga JC, Lassaletta L, Moreno AG (2010) Ground-living spider assemblages from Mediterranean habitats under different management conditions. J Arachnol 38:258-269

Baselga A et al (2007) Disentangling distance decay of similarity from richness gradients: response to Soininen. Ecography 30:838-841

Bates D, Maechler M, Bolker B, Walker S (2015) _lme4: linear mixed-effects models using Eigen and S4_. $\mathrm{R}$ package version 1.1-8. http://CRAN.R-project.org/package=lme4

Bell JR, Wheater CP, Cullen WR (2001) The implications of grassland and heathland management for the conservation of spider communities: a review. J Zool 255:377-387

Bergeron JAC, Spence JR, Volney WJA, Pinzon J, Hartley DJ (2013) Effect of habitat type and pitfall trap installation on captures of epigaeic arthropod assemblages in the boreal forest. Can Entomol 145:547-565

Bivand R, Altman M, Anselin L, Assunçao R, Berke O, Bernat A, Blanchet G, Blankmeyer E, Carvalho M, Christensen B, Chun Y, Dormann C, Dray S, Halbersma R, Krainski E, Legendre P, Lewin-Koh N, Li H, Ma J, Millo G, Muller W, Ono H, Peres-Neto P, Piras G, Reder M, Tiefelsdorf M, Yu D (2014) spdep: spatial dependence: weighting schemes, statistics and models. R package version 0.5-71

Blanchet FG, Bergeron JAC, Spence JA, He F (2013) Landscape effects of disturbance, habitat heterogeneity and spatial autocorrelation for a ground beetle (Carabidae) assemblage in mature boreal forest. Ecography 36:636-647

Bristowe WS (1958) World of spiders. William Collins \& Sons Ltd., London

Calaciura B, Spinelli O (2008) Management of Natura 2000 habitats. 6210 semi-natural dry grasslands and scrubland facies on calcareous substrates (Festuco-Brometalia) (*important orchid sites). European Commission. http://ec.europa.eu/environment/nature/natura2000/management/habitats/pdf/6210_Seminatural_dry_grasslands.pdf

Cardoso P, Pekár S, Jocqué R, Coddington JA (2011) Global patterns of guild composition and functional diversity of spiders. PLoS ONE 6:e21710

Chao A (2005) Species richness estimation. In: Balakrishnan N, Read CB, Vidakovic B (eds) Encyclopedia of statistical sciences. Wiley, New York, pp 7909-7916

Colwel RK (2013) EstimateS and user's guide: statistical estimation of species richness and shared species from samples. Version 9.1. http://purl.oclc.org/estimates. Accessed 20 April 2017

Corcuera P, Valverde PL, Jiménez ML, Ponce-Mendoza A, De la Rosa G, Nieto G (2015) Ground spider guilds and functional diversity in native pine woodlands and eucalyptus plantations. Environ Entomol 45:292-300

Dawson JC, Huggins DR, Jones SS (2008) Characterizing nitrogen use efficiency in natural and agricultural ecosystems to improve the performance of cereal crops in low-input and organic agricultural systems. Field Crop Res 107:89-101

DEFRA (2013) Agriculture in the United Kingdom 2012. DEFRA. https://www.gov.uk/government/collections/agriculture-in-the-united-kingdom. Accessed 18 Feb 2017

Dennis P, Young MR, Gordon IJ (1998) Distribution and abundance of small insects and arachnids in relation to structural heterogeneity of grazed, indigenous grasslands. Ecol Entomol 23:253-264

Dennis P, Young MR, Bentley C (2001) The effects of varied grazing management on epigeal spiders, harvestmen and pseudoscorpions of Nardus stricta grassland in upland Scotland. Agric Ecosyst Environ $86: 39-57$

Dennis P, Skartveit J, McCracken DI, Pakeman RJ, Beaton K, Kunaver A, Evan DM (2008) The effects of livestock grazing on foliar arthropods associated with bird diet in upland grasslands of Scotland. J Appl Ecol 45:279-287

Dennis P, Skarveit J, Kunaver A, McCracken DI (2015) The response of spider (Araneae) assemblages to structural heterogeneity and prey abundance in sub-montane vegetation modified by conservation grazing. Glob Ecol Conserv 3:715-728

Denno RF (1980) Ecotope differentiation in a guild of sap feeding insects on the Salt Marsh Grass, Spartina patens. Ecology 61:702-714

Dielh E, Mader VL, Wolters V, Birkhofer K (2013) Management intensity and vegetation complexity affect web-building spiders and their prey. Oecologia 173:579-589 
Digweed SC, Currie CR, Carcamo HA, Spence JR (1995) Digging out the "digging-in effect" of pitfall traps: influences depletion and disturbance on catches of ground beetles (Coleoptera: Carabidae). Pedobiologia 39:561-576

Dixon JM (1982) Sesleria albicans kit. ex Schultes (S. varia (Jacq.) Wettst. S. caerulea (L.) Ard. ssp. calcarea (Celak.) Hegi). J Ecol 70:667

Duelli P, Obrist M (2003) Regional biodiversity in an agricultural landscape: the contribution of seminatural habitat islands. Basic Appl Ecol 4:129-138

Dufrene M, Legendre P (1997) Species assemblages and indicator species: the need for a flexible asymmetrical approach. Ecol Monogr 67:345-366

Fischer M, Stocklin J (1997) Local extinctions of plants in remnants of extensively used calcareous grasslands 1950-1985. Conserv Biol 11:727-737

Fox J, Weisberg S (2011) An $\{\mathrm{R}\}$ companion to applied regression, 2nd edn. Thousand Oaks: Sage. http:// socserv.socsci.mcmaster.ca/jfox/Books/Companion

Fuller R, Gough S (1999) Changes in sheep numbers in Britain: implications for bird populations. Biol Conserv 91:73-89

García RR, Ocharan FJ, García U, Osoro K, Celaya R (2010) Arthropod fauna on grassland-heathland associations under different grazing managements with domestic ruminants. CR Biol 333:226-234

Gardner SM, Hartley SE, Davies A, Palmer SCF (1997) Carabid communities on heather moorlands in northeast Scotland: the consequences of grazing pressure for community diversity. Biol Conserv 81:275-286

Gibson CWD, Hambler C, Brown VK (1992) Changes in spider (araneae) assemblages in relation to succession and grazing management. J Appl Ecol 29:132-142

Grant SA, Suckling DE, Smith HK, Torvell L, Forbes TDA, Hodgson J (1985) Comparative studies of diet selection by sheep and cattle: the hill grasslands. J Ecol 73:87-1004

Greenslade PJM (1964) Pitfall trapping as a method for studying populations of Carabidae (Coleoptera). J Anim Ecol 33:301-310

Harrison XA (2014) Using observation level random effects to model overdispersion in count data in ecology and evolution. Peer J 2:e616

Harvey PR, Neillst DR, Telfer MG (eds) (2002) Provisional atlas of British spiders (Arachnida, Araneas), vols 1 and 2. Biological Records Centre, Huntingdon

Haysom KA, McCracken Foster GN, Sotherton NW (2004) Developing grassland conservation headlands: response of carabid assemblage to different cutting regimes in a silage field edge. Agric Ecosyst Environ 102:263-277

Hester AJ, Baillie GJ (1998) Spatial and temporal patterns of heather use by sheep and red deer within natural heather/grass mosaics. J Appl Ecol 35:772-784

Hothorn T, Bretz F, Westfall P (2008) Simultaneous inference in general parametric models. Biometr J 50:346-363

Joint Nature Conservation Committee (2007). JNCC and the UK statutory nature conservation agencies Lowland Grassland Lead Coordination Network 2007. Second Report by the United Kingdom under Article 17 on the implementation of the Directive from January 2001 to December 2006. Audit Trail Supporting Conservation status assessment for Habitat: H6210: semi-natural dry grasslands and scrubland facies: on calcareous substrates (Festuco-Brometalia)

Joint Nature Conservation Committee (2013) Third report by the UK under Article 17 on the implementation of the habitats directive from January 2007 to December 2012. JNCC, Peterborough

Koleff P, Gaston KJ, Lennon JJ (2003) Measuring beta diversity for presence-absence data. J Anim Ecol 72:367-382

Langellotto GA, Denno RF (2004) Responses of invertebrate natural enemies to complex-structured habitats: a meta-analytical synthesis. Oecologia 139:1-10

Littlewood NA, Pakeman RJ, Woodin SJ (2006) The response of plant and insect assemblages to the loss of Calluna vulgaris from upland vegetation. Biol Conserv 128:335-345

Lyons A, Ashton PA, Powell I, Oxbrought A (2017) Impacts of contrasting conservation grazing management on plants and carabid beetles in upland calcareous grasslands. Agric Ecosyst Environ 244:22-31

Maddock A. (ed) (2008) UK biodiversity action plan priority habitat descriptions: Upland Calcareous Grassland. Joint Nature Conservancy Committee, Peterborough. http://jncc.defra.gov.uk/page-5706. Accessed 17 Nov 2016

Maelfait JP, De Keer R (1990) The border zone of an intensively grazed pasture as a corridor for spiders Araneae. Biol Conserv 54:223-238

Magurran AE (1988) Ecological diversity and its measurement. Princeton University Press, Princeton, pp $7-11$

Magurran AE (2004) Measuring biological diversity. Blackwell, Oxford, p 256 
Mazia CN, Chaneton EJ, Kitzberger T (2006) Small-scale habitat use and assemblage structure of ground dwelling beetles in Patagonian shrub steppe. J Arid Environ 67:177-194

McCune B, Grace JB, Urban DL (2002) Analysis of ecological communities. MJM Software design, Gleneden Beach

McFerran DM, Montgomery WI, McAdam JH (1994) Effects of grazing intensity on heathland vegetation and ground beetle assemblages of the uplands of County Antrim, North-east Ireland. Biol Environ Proc R Irish Acad 94:41-52

McNett B, Rypstra A (2000) Habitat selection in a large orb-weaving spider: vegetational complexity determines site selection and distribution. Ecol Entomol 25:423-432

Merrett P (1976) Changes in the ground-living spider fauna after heathland fires in Dorset. Bulletin of the British Arachnology Society 3:214-221

Merrett P (1990) A review of the nationally notable spiders of Great Britain. NCC, Peterborough

Morris MG (2000) The effects of structure and its dynamics on the ecology and conservation of arthropods in British grasslands. Biol Conserv 95:129-142

Neuwald AF, Green P (1994) Detecting patterns in protein sequences. J Mol Biol 239:698-712

Niemela J, Spence JR, Langor DW, Haila Y, Tukia H (1993) Logging and boreal ground beetle assemblages on two continents: implications for conservation. In: Gaston KJ, New TR, Samways MJ (eds) Perspectives in insect conservation. Intercept Ltd., Andover, pp 29-50

Oksanen J, Blanchet FG, Friendly M, Kindt R, Legendre P, McGlinn D, Minchin PR, O'Hara RB, Simpson GL, Solymos P, Stevens MHH, Szoecs E, Wagner H (2016). Vegan: community ecology package. R package version 2.4-1. https://CRAN.R-project.org/package=vegan

Oxbrough A, Gittings T, Kelly TC, O’Halloran J (2009) Can Malaise traps be used to sample spiders for biodiversity assessment? J Insect Conserv 14:169-179

Oxbrough A, French V, Irwin S, Kelly TC, Smiddy P, O'Halloran J (2012) Can mixed species stands enhance arthropod diversity in plantation forests? For Ecol Manag 270:11-18

Pinzon J, Spence JR, Langor DW (2013) Effects of prescribed burning and harvesting on ground-dwelling spiders in the Canadian coreal mixedwood forest. Biodivers Conserv 22:1513-1536

Poschlod P, Wallis de Vries MF (2002) The historical and socioeconomic perspective of calcareous grasslands-lessons from the distant and recent past. Biol Conserv 104:361-376

Poschlod P, Bakker JP, Kahmen S (2005) Changing land use and its impact on biodiversity. Basic Appl Ecol 6:93-98

R Development Core Team (2016) R: a language and environment for statistical computing. R Foundation for Statistical Computing, Vienna. http://www.R-project.org

Roberts MJ (1993) The spiders of Great Britain and Northern Ireland. Harley Books, Colchester

Roberts WD (2015) labdsv: ordination and multivariate analysis for ecology. R package version 1.7-0. http:// CRAN.R-project.org/package=labdsv

Robinson JV (1981) The effect of architectural variation in habitat on a spider community: an experimental field study. Ecology 62:73-80

Rodwell JS (1992) British plant communities. Volume 3: grasslands and montane communities. Cambridge University Press, Cambridge

Rodwell JS, Morgan V, Jefferson RG, Moss D (2007) The European context of British Lowland Grasslands. JNCC Report, No. 394. www.jncc.gov.uk/pdf/jncc394_webpt1.pdf

Roesch V, Tscharntke T, Scherber C, Batáry P (2013) Landscape composition, connectivity and fragment size drive effects of grassland fragmentation on insect communities. J Appl Ecol 50:387-394

Schweiger O, Maelfait E, Van Windergarden W, Hendrickx F, Billeter R, Speelmans M, Augenstein I, Aukema B, Aviron S, Bailey D, Bukacek R, Burel F, Diekotter T, Dirksen J, Frenzel M, Herzog F, Liira J, Roublova M, Bugter R (2005) Quantifying the impact of environmental factors on arthropod communities in agricultural landscapes across organizational levels and spatial scales. J Appl Ecol 42:1129-1139

Spider and Harvestman Recording Scheme Website (2017) http://srs.britishspiders.org.uk/portal.php/p/ Summary/s/Jacksonella+falconeri. Accessed 6 April 2017

Taboada A, Kotze DJ, Salgado JM, Tarrega R (2010) The value of semi-natural grasslands for the conservation of carabid beetles in long-term managed forested landscapes. J Insect Conserv 15:573-590

Thomas R (2017) Data analysis with R statistical software: a guidebook for scientists. Eco-Explore, Machen

Turnbull AL (1973) Ecology of true spiders (Araneomorphae). Annu Rev Entomol 18:305-348

Uetz GW (1991) Habitat structure and spider foraging. Habitat structure. Springer, New York, pp 325-348

van Klink R, Rickert C, Vermeulen R, Vorst O, Wallis de Vries MF, Bakker JP (2013) Grazed vegetation mosaics do not maximize arthropod diversity: evidence from salt marshes. Biol Conserv 164:150-157 
Vickery JA, Tallowin JR, Feber RE, Asteraki EJ, Atkinson PW, Fuller RJ, Brown VK (2001) The management of lowland neutral grasslands in Britain: effects of agricultural practices on birds and their food resources. J Appl Ecol 38:647-664

Vlijm L, Kessler-Geschiere AM (1967) The phenology and habitat of Pardosa monticola, P. nigriceps and P. pullata (Araneae, Lycosidae). J Anim Ecol 36:31-56

Wallis de Vries MF, Poschlod P, Willems JH (2002) Challenges for the conservation of calcareous grasslands in north western Europe: integrating the requirements of flora and fauna. Biol Conserv 104:265-273

Willems JH (2001) Problems, approaches, and results in restoration of Dutch calcareous grassland during the last 30 years. Restor Ecol 9:147-154

Woodcock BA, Potts SG, Tscheulin T, Pilgrim E, Ramsey AJ, Harrison-Cripps J, Brown VK, Tallowin JR (2009) Responses of invertebrate trophic level, feeding guild and body size to the management of improved grassland field margins. J Appl Ecol 46:920-929

World Spider Catalogue (2017) World Spider Catalogue. Natural History Museum Bern. http://wsc.nmbe. ch, version 17.5. Accessed 2 Mar 2017 